\title{
The Competitiveness of Indonesian Halal Food Exports in Global Market Competition Industry
}

\author{
Nikmatul Masruroh \\ Institut Agama Islam Negeri (IAIN) Jember, Indonesia \\ email: nikmatul.masruroh82@gmail.com
}

\begin{abstract}
This research aims to discuss the implementation of halal value chain policies in Indonesia and the impact on the export competitiveness of the halal food industry. This research uses a qualitative approach with a phenomenological type through data collection by interviewing export business actors in the halal food industry. This research states that the halal value chain application has been stated in the Halal Product Guarantee Law No. 33 of 2014, where the law requires all food entrepreneurs to carry out halal certification. The halal value chain in Indonesia applies the principle of traceability which makes Indonesian halal food products competitive. The application of the principle of traceability is different from other countries, making halal food products produced by Indonesia acceptable to importing countries, especially OIC countries. This research intends to encourage the government to develop and increase halal food exports through literacy to all entrepreneurs and MSMEs about halal certification. The originality of this research lies in the analysis of the halal value chain policies applied in Indonesia to export products.
\end{abstract}

Keywords: halal food; halal value chain; traceability

\begin{abstract}
Abstrak: Penelitian ini bertujuan untuk membahas implementasi kebijakan rantai nilai halal di Indonesia dan dampaknya terhadap daya saing ekspor industri makanan halal. Penelitian ini menggunakan pendekatan kualitatif dengan tipe fenomenologis melalui pengumpulan data dengan mewawancarai pelaku usaha ekspor pada industri makanan halal. Penelitian ini menyatakan bahwa penerapan rantai nilai halal telah tertuang dalam Undang-Undang Jaminan Produk Halal Nomor 33 Tahun 2014, dimana undang-undang tersebut mewajibkan semua pengusaha makanan untuk melakukan sertifikasi halal. Rantai nilai halal di Indonesia menerapkan prinsip ketertelusuran yang membuat produk makanan halal Indonesia berdaya saing. Penerapan prinsip ketertelusuran berbeda dengan negara lain, membuat produk pangan halal yang diproduksi Indonesia dapat diterima oleh negara-negara pengimpor, khususnya negara-negara OKI. Penelitian ini bermaksud mendorong pemerintah untuk mengembangkan dan meningkatkan ekspor makanan halal melalui literasi kepada seluruh pengusaha dan UMKM tentang sertifikasi halal. Orisinalitas penelitian ini terletak pada analisis kebijakan rantai nilai halal yang diterapkan di Indonesia terhadap produk ekspor.
\end{abstract}

Kata Kunci: makanan halal; rantai nilai halal; ketertelusuran

Economica: Jurnal Ekonomi Islam - Volume 11, Nomor 1 (2020) 
Nikmatul Masruroh

\section{Introduction}

Indonesia is positioned in the first rank as a consumer of halal food products. Yet, Indonesia has not become the number 1 exporter in the world halal food industry. According to the 2020/2021 Global Islamic Economic Indicator (GIEI) report, Indonesia managed to occupy the world's fourth tool, but it has not been comparable to the expenditure made. According to the 2019/2020 GIEI report, Indonesia has not been able to occupy the top 10 in the competition for the halal food industry. As contradictory as it is, efforts to develop the halal food industry continue so that Indonesia can rank $4^{\text {th }}$ in the world's halal food industry (Mostafa 2020).

The food and beverage sector also has a productive market potential, especially in halal-certified food and beverages (Yusoff, Yusof, and Hussin 2015). Several Southeast Asian countries are currently developing the halal food industry to strengthen competition in the global market. While Indonesia is the largest Muslim country globally, expanding the halal food industry has two target benefits: protecting domestic consumers from consuming nonhalal products and earning income from the export of halal products (Ratanamananeichat \& Rakkarn, 2013). In 2021, Indonesia has realized the development of the halal food industry by establishing 3 Halal Industrial Estates/Kawasan Industri Halal (KIH). KIH is located in Serang (Banten) under the name Modern Cikande Industrial Estate, Safe n Lock Halal Industrial Park in Sidoarjo (East Java), and the Bintan Inti Halal Hub Halal Industrial Estate in Bintan Regency. The three KIHs are clear evidence of the government's seriousness in making Indonesia the World Halal Center in 2024.

The benefits of earning income from the export of halal food have become a trend in several countries. Currently, Brazil is the largest supplier of halal poultry to the Middle East, UAE is the center of the world's Islamic economy, Thailand is the largest halal food producer in the world and have a vision of 
"World Halal Kitchen", and Australia right now is the largest meat supplier country to the Middle East (HDC, 2016). Therefore, the question that must be discussed and explored is how are the implementation of the halal value chain in Indonesia and the impact of the halal value chain system on the competitiveness of halal food exports in the global market?.

This study addresses two questions above. First, several previous studies related to the halal food industry have often been performed along with the halal industry development in Indonesia. In 2018, research on the "Model for the Development of the Halal Food Industry in Indonesia" by Waharini and Purwantini (2018) illustrated that the halal industry in Indonesia would be more competitive if it cooperates with Islamic banking. The research conducted by Waharini and Purwantini (2018) aims to explore the role of Islamic banking in developing the halal food industry in Indonesia. The method used is a qualitative method with a literature review. This research gives the result that the role of Islamic banking is not only limited to shariabased financing that is free of riba (interest), maysir (uncertainty), and gharar (gambling). But also at all stages of the production process (halal value chain management). The critical role that Islamic banking can play is to develop and improve the halal food industry, including the three halal integrity processes. The first is at the halal control stage, the second is the logistics process, and the last is the halal verification stage (Waharini and Purwantini 2018).

Dyah Ismowati researched the halal food industry in 2015 with the title "Halal Food Marketing: A Case Study On Consumer Behavior of Chicken Processed Food Consumption In Central Part Of Java, Indonesia". This research focuses on the behavior of UK consumers in consuming chicken in Yogyakarta and surrounding areas. The approach used is a quantitative approach by spreading surveys to 292 respondents, and it stated that in making consumption, a consumer considers the halalness of the food. However, this consideration falls after considering the taste of the food. Although consumer's knowledge about halal food seems to vary, from the

Economica: Jurnal Ekonomi Islam - Volume 11, Nomor 1 (2020) 
results of this study, all respondents stated that halal and nutritional factors also affect their consumption behavior (Ismoyowati 2015). Research on the halal food industry is also related to the halal value chain reviewed by Soon et al. (2017). The research is entitled "Halal Integrity In the Food Supply Chain". This research departs from the lack of halal integrity in the conventional food industry. This study tries to develop critical awareness in building halal integrity in the food supply chain circulating in the Muslim consumer market. The results of this study indicate that there are various interpretations of halal in the food industry. The varied interpretation depends on the Islamic legal thought that is owned by each country. This study proposes a halal food supply chain starting from raw materials to ready-to-eat ingredients or starting from the agricultural process to cooking it. Therefore, there is a need for a proposal for halal integrity (May et al., 2017).

Chiratus Ratanamaneichar and Sakchai Rakkarn (2013) studied the Quality Assurance of halal food. Quality Assurance of halal food must exist in Indonesia to regulate the export and import of halal food. Since Indonesia is the largest market in the Halal food industry in Asia, Indonesia must have a security system in the halal food trade route, commonly known as Security Strategy and Non-Tariff Barriers (NTBs). This study focuses on halal food export using halal certificates, halal market surveys, and regulations regarding halal products. This research is compiled with "Quality Assurance Development of Halal Food Products For Export to Indonesia" (Ratanamananeichat \& Rakkarn, 2013). Some of these studies have similarities in the study, namely studying the halal food industry, but they have differences in terms of the focus of the study. This study emphasizes the analysis of halal value chain policies that apply in Indonesia and the impact of halal value chain system policies on the competitiveness of halal food exports in the global market. 


\section{Literature review}

\section{Halal value chain concept}

The issue of consumer choice on halal-labeled food has now become a lifestyle (Kusuma et al. 2013). Abu-alhaija (2018) stated that a person's level of religiosity is related to their buying behavior for a commodity. Halal standards are a universal indicator for product quality assurance and living standards (Hameeda et al. 2016). Halal is usually only associated with material things. However, in Islam, halal includes deeds and work, commonly called Muamalah (al Qardhawi, 1993). According to Islamic Sharia law, Halal can be defined as a quality standard and is used in every activity carried out by Muslims (Saabar and Ibrahim 2014). Muslims choose halal products and services as a form of obedience to Islamic Sharia law. As it is said in QS al Baqarah: 168:

"O people, eat by you from whatever is on the face of the earth that is lawful and thoyyib, and do not follow the steps of the devil, because indeed the devil is a real enemy for you".

From the verse above, it can be understood that the consumption carried out by Muslims must be "halal thoyyibah" (hygienic, healthy \& wholesome) consumption. Halal must be clean, pure, and made following the provisions of Islamic law, including what is forbidden are pigs and their derivatives, blood and their derivatives, animals slaughtered without mentioning the name of Allah, carrion, wild animals, and khamr (Azzhaili, 1985). Therefore, this concept gave birth to a halal supply chain in the food industry, indicating that halal values are very concerned with downstream and upstream products, starting from the raw materials used to make these products. Then we can see the continuation of this halal supply chain in product development using the halal value chain (Ismoyowati 2015). In the halal supply chain, this pays attention to the halalness of a product and its effects. Because in terms of consumption, Islam teaches Islamic values, and health aspects must also be prioritized. When a Muslim only consumes halal goods without paying

Economica: Jurnal Ekonomi Islam - Volume 11, Nomor 1 (2020) 
Nikmatul Masruroh

attention to the thayyibah aspect of the goods consumed, then what happens is a loss, as stated in the letter an Nahl verse 114:

"So eat what is lawful and good from the sustenance that Allah has given you; and be grateful for the favors of Allah, if you worship Him alone."

In addition, it is also reinforced by the hadith narrated by Muslim:

"From Abu Hurairah RA said, the Messenger of Allah said: "O people! Verily Allah is good, accepts nothing but good. He ordered the believers what was commanded the messengers. "O messengers, eat from what is good and do good deeds, for indeed we know what you do." "Eat from what is good for what We provide for you." Then the Prophet said there was a man who traveled far, his hair was disheveled and dirty. He raised his hands up while praying: 0 my Lord, 0 my Lord ", while what he eats and drinks and what he wears comes from the forbidden, how can his prayer be accepted " (HR. Muslim).

From an Nahl verse 114 and al Baqarah verse 168 quoted earlier, the word "eating" in verse is human activity. Human activity covers basic human needs, besides consuming food, is a supporter of all human activities. Without eating, humans will be weak and unable to carry out activities This verse commands to consume still halal food is good. Halal food is food that is not haram; that is, it is not forbidden by religion to eat it. Two things are haraam: haraam, such as carrion, pork, and blood. Another type of haram is not a substance, such as eating food that is not permitted by the owner to be consumed or used. Food or activities related to the body are often used by Satan to deceive humans. Satan has footprints; he plunges humans because Satan is a natural enemy for humans.

From the philosophy above, the halal value chain was developed. The development of the halal value chain concept begins with the supply chain management (SCM) concept, a network of companies that work together to create and deliver a product to the hands of consumers (Jaya and Luhur 2018). Supply chain management (SCM) is applied to reduce production costs (Waharini and Purwantini 2018). On the other hand, the halal supply chain is 
used by companies to maintain and maintain product halalness (Hameeda et al. 2016). Halal integrity is the keyword in the halal value chain (Abdul Rahman et al. 2018). The following is an example of a halal supply chain image to be able to maintain product halalness. Only halal species may be bred, and these halal species do not consume haram fodder (May et al., 2017). All processes related to output must go through a halal process, starting from obtaining raw materials, how to make, how to wrap up how to sell must go through a halal way.

Figure 1. Halal Supply Chain from Raw Materials to Finished Goods

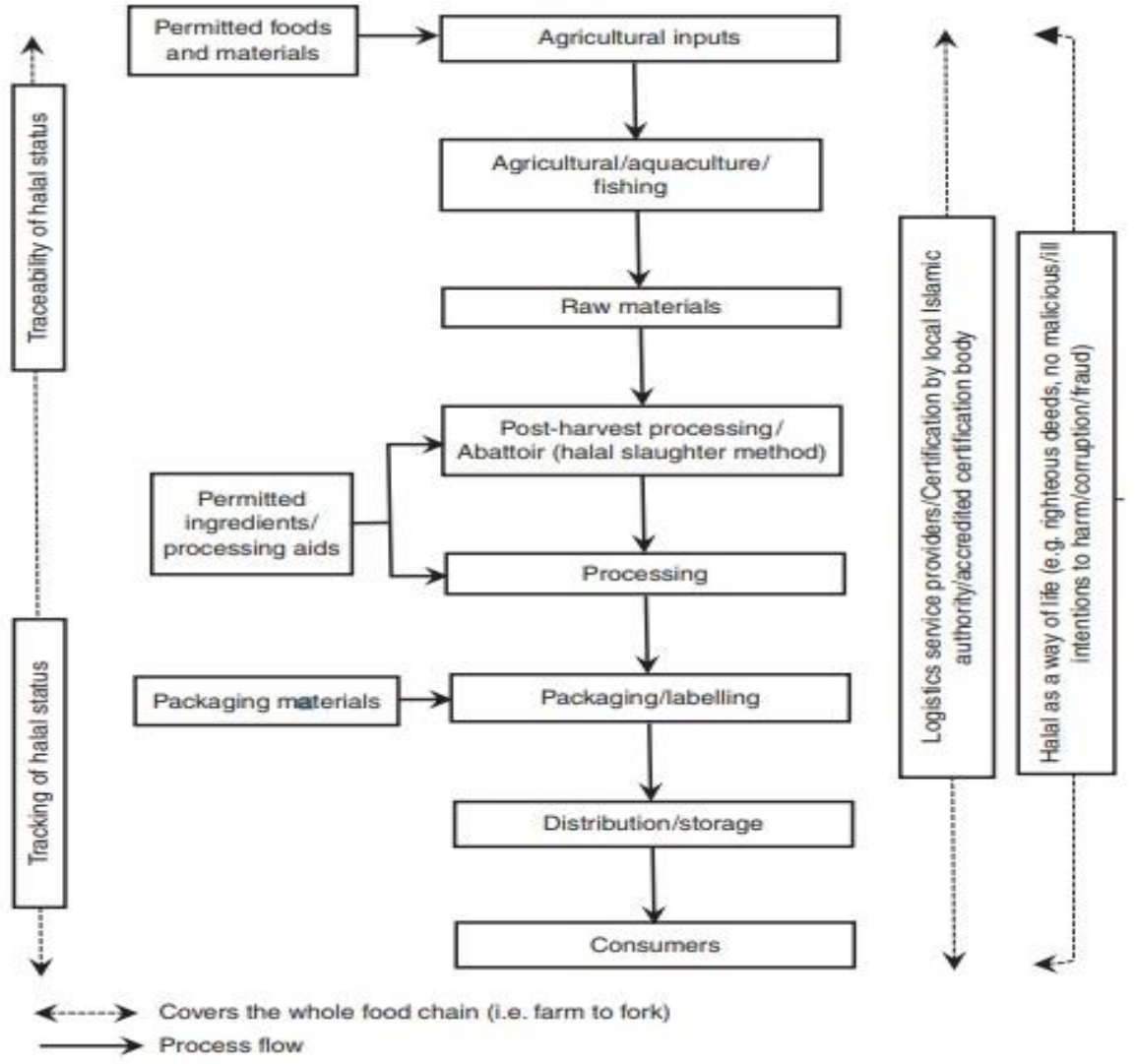

Source: Mohammed, Wang, and Li (2017)

Economica: Jurnal Ekonomi Islam - Volume 11, Nomor 1 (2020) 
Based on Figure 1, halal integrity at every level of the production process must remain the main priority of business actors. Process stages starting from raw materials (input), post-harvest processing, packaging and labeling, storage/distribution to the hands of consumers (Waharini and Purwantini 2018). Based on Law No. 33 of 2014, the halal value chain process can be achieved if entrepreneurs apply for halal certification from raw materials to products in the hands of consumers. The regulations used for Indonesian halal certification are in addition to the law on guaranteeing halal products. It is also mentioned in Law No. 11 of 2020 concerning Job Creation, PP No. 31 of 2021 concerning the implementation of the field of halal product guarantees, PMK No. 57 of 2021 concerning service rates for public service agencies, the Halal Product Assurance Organizing Agency and PMA No. 26 of 2019 regarding the Implementation of Halal Product Assurance. Of these several laws, in realizing the halal value chain, the submission process was implemented in figure 2 .

The process begins with the submission of halal certification to BPJPH. BPJPH inspects documents and determines LPH. Meanwhile, there are still 3 Halal Inspection Institutions (LPH) in Indonesia, namely LPPOM MUI, SUCOFINDO, and Surveyor Indonesia. LPPOM MUI uses HAS 23000 in determining whether a company can have halal certification or not. According to HAS 23000,11 points must be met. The standardized food by HAS 23000 ,

Figure 2. The Halal Procedure it Was Processed

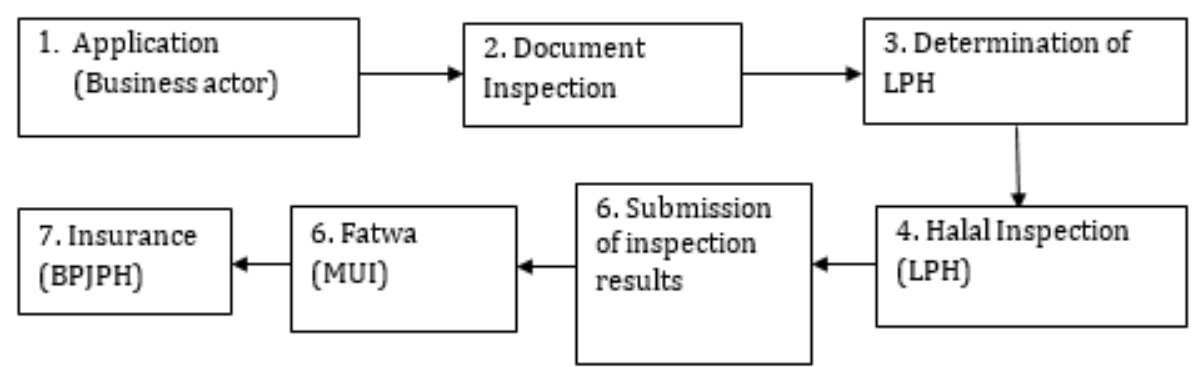

Source: www.kneks.go.id 
is halal food and healthy food. After the company selects LPH, then there is an inspection by LPH. Submission of the results of the examination by LPH is given to the MUI fatwa commission. If it is fulfilled, the MUI fatwa will be issued, and BPJPH will issue a halal certificate based on the MUI fatwa.

\section{Exports between countries}

Currently, halal food has a broad market share because those who want halal food are from Muslim countries and non-Muslim countries (AtalanHelicke 2015). However, the market share of halal food exports is open to all countries, so international trade in halal food is a separate concept in that country. Especially in Indonesia, which has the most considerable halal potential globally but has not become a major player in the international trade of halal food (Thomson Reuters, State of The Global Islamic Economic Report 2020/2021).

In international trade practice, countries work together to export and import their domestic products. As a country that adheres to an open economic system, Indonesia also does the same thing to establish bilateral relations between countries and provide additional state revenues (Elias and Noone 2016). Because one of the factors that influence state revenue comes from the export and import sector (Pearson et al. 2017).

$$
\mathrm{Y}=\mathrm{C}+\mathrm{I}+\mathrm{G}+(\mathrm{XM})
$$

$\mathrm{Y}$ is state income

C = consumption

I $\quad$ = investment

$\mathrm{G} \quad=$ government spending

$\mathrm{X}=$ export

$\mathrm{M} \quad=$ Import

Economica: Jurnal Ekonomi Islam - Volume 11, Nomor 1 (2020) 
Nikmatul Masruroh

From the above formulation, it can be understood that the increase in products (goods and services produced by a country, will increase the country's income (Y). Because the export sector is a type of aggregate expenditure, it can affect national income. "When exports increase, then aggregate expenditure will increase so that it can increase national income", although "if national income increases, exports do not necessarily increase or change" (Koo 2016). In practice, exports can be divided into 2, namely direct and indirect exports (Romer, 2017). Direct exports, namely, the exporting country, cooperates with exporters who are in the destination country. Sales are made through company sales representatives. The advantage of this model is that production is centralized in the country of origin and has better control over distribution. The drawbacks are higher transportation costs for large-scale products and trade barriers and protectionism (Blanchard, 2017).

Meanwhile, indirect exports sell goods through exporters from the country of origin and then sold by export management companies (export management companies) and export trading companies (Blanchard, 2017). The advantage of this model is that production resources are concentrated, and there is no need to handle exports directly. Weaknesses, lack of control over distribution and lack of knowledge of operations in the country (Romer, 2017). An exporter can choose one of these models.

Of course, in the export process, the goal of a country, apart from strengthening bilateral relations between nations, is the most important thing to gain profit from the trade because later will be used as income. If the profit earned is high, the amount of state revenue will also increase. Therefore, efforts are needed to increase the competitiveness of exports of halal-based products and services in Indonesia to contribute to Indonesia's economic growth (Endang S Soesilowati 2010). Achieving this requires a strategy. One strategy that can be used is to increase the competitive advantages of exported halal food. Indonesia must have superior products and characteristics related

Economica: Jurnal Ekonomi Islam - Volume 11, Nomor 1 (2020) https://journal.walisongo.ac.id/index.php/economica 
to exported halal food so that consumers are interested in the products offered (Ruiz-bejarano 2017).

There is a feedback relationship between exports and output, in this case, halal food. Based on the opinion of Helpman and Krugman (1985), it is stated that exports can increase from the realization of economies of scale from higher gains in productivity. This means that if there is excess halal food production and can be sold abroad, the country will gain more profit. If the profit is excessive, there will be economic growth (Pack, 1988).

\section{Methods}

This study uses a qualitative approach to be able to answer the questions asked in this study. This type of research used phenomenology. This type used to reveal the experience of business actors in implementing a halal assurance system with the principle of treacibility, thus creating a halal value chain in food products.

Data were obtained using interviews and FGDs with parties related to halal food certification for business actors. The resource persons included: Edy Zain as Operations Manager, Yudi Haryanto (Secretary of Halal Supervisor), Farida Idajati (Chairman of Halal Supervisor), Kartika Anggraeni (Marketing Manager), Erlambang (Chairman of the Indonesian Export Trade Association for East Java) and Sukoso (Head of BPJPH). The discussion was strengthened by observations made to see the halal value chain process in the production process.

\section{Result and discussion}

\section{Implementation of halal value chain policy for halal food in Indonesia}

The halal value chain is a process of the Halal supply chain of halal food products in Indonesia. In halal food production, the flow of this halal value 
chain is in every integrity or value attribute of a product produced. Based on an interview with Sukoso, the Head of BPJPH Indonesia said:

"The halal food supply chain must come from halal raw materials. The manufacturing process must be pure, and the tools used are holy. The method of obtaining raw materials is also halal until the packaging and labeling process must be a halal process."

Sukoso strengthened his argument by giving an example of a halalan thoyyiba canteen at Brawijaya University, Malang. Thus, the process of internalizing the halal value chain is continuously being carried out. If someone wants to trace it, the policy of developing halal-labeled food in Indonesia is marked by the promulgation of Law no. 33 of 2014 concerning Halal Product Guarantee. This law mandates the establishment of BPJPH. BPJPH was inaugurated on October 112017 , under the Ministry of Religion to implement Law no. 33 of 2014.

Halal Product Guarantee (JPH) is held to provide comfort, security, safety, and certainty of the availability of halal products for those who consume and use the product. The aim is, of course, an increase in added value for business actors to produce or sell products. BJPH, as an official institution in overseeing the halal industry in Indonesia has the authority, among others: formulating and establishing JPH policies, setting norms, standards, procedures, and criteria for JPH, registering halal certificates on foreign products, conducting socialization, education, and publication of halal products, conducting accrediting LPH, registering halal auditors, supervising JPH, fostering halal auditors, and collaborating with domestic and foreign institutions in the field of JPH implementation.

This authority will continue to be increased, often with the enactment of Law no. 33 of 2014 Article 4 concerning incoming products Products that enter, circulate and trade in the territory of Indonesia must be certified halal. All imported goods from any country must have a halal certificate before spreading in Indonesia. In addition, Article 26 of the JPH Law states that 
business actors who produce products from materials derived from prohibited materials are exempt from applying for a Halal Certificate and are required to include non-halal information on the product. This policy is continued by Article 67 of the JPH Law, and the obligation to have a halal certificate comes into effect 5 (five) years since the JPH Law was enacted.

This law gives the green light to all industries to improve themselves, namely by starting a branding as a halal product. In addition, the establishment of the Halal Industrial Estate is a concrete form of realizing Indonesia's ideals as a Halal Center in the World. The Halal Industrial Estate will start on the island of Java and then continue outside Java. The only industries that can enter the halal industrial area are those that have a halal certificate. If you do not have a certificate, the place is outside the room (Arief Sanjaya, JIEP, 2018). Currently, there is a process of accelerating halal certification for street vendors and IKM, especially street vendors who are most in-demand by the public, such as traders of chicken noodles, meatballs, and fried rice (Sukoso, 2018).

Figure 3. Halal Certification Process

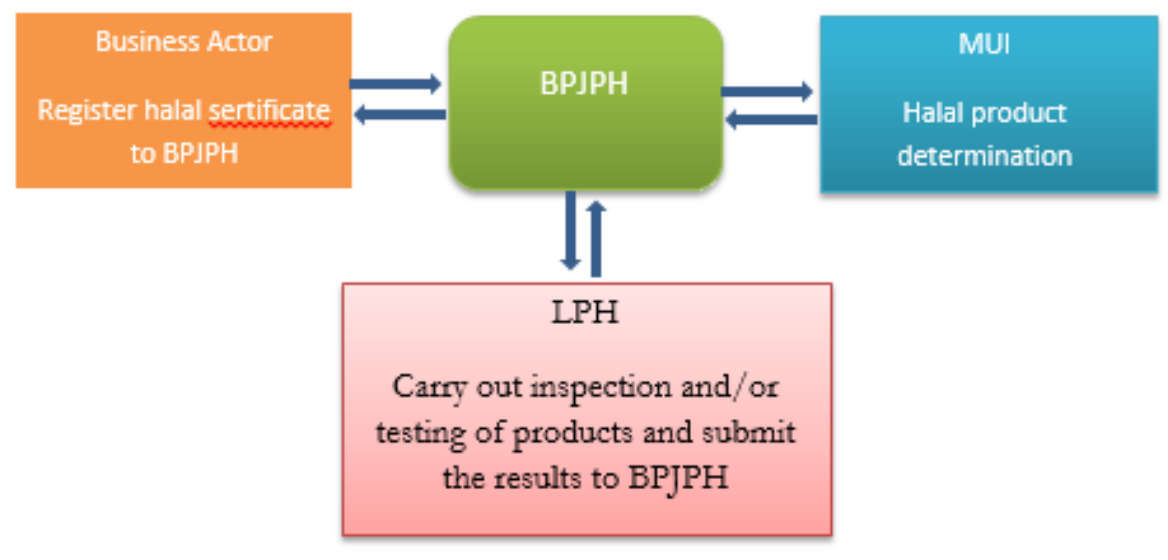

Source: www.kneks.go.id

Economica: Jurnal Ekonomi Islam - Volume 11, Nomor 1 (2020) 
From the JPH Law, it is stated that all industries must have a halal certificate. Halal certification is a written acknowledgment by BPJPH regarding the halalness of a product based on a written halal fatwa issued by the MUI. Currently, all entrepreneurs and owners of MSMEs and SMEs are required to carry out a certification process. The following is the process for applying for halal certification can see in figure 3 .

From the flow above, it can be explained that business actors register halal certification with BPJPH. The BJPH provides files to LPH, tests the products to be certified, then gives them to MUI for certification and issuance of certificates. The series of plots below explain the flow:

In addition to the two flows above, Figure 4 illustrates the draft model for halal certification after implementing the current model. The flow below gives us knowledge that MUI is not a single actor in the halal certification process. $\mathrm{BPJPH}$ was formed as an extension of the Ministry of Religion. All halal methods are under the auspices of the Ministry of Religion. The Ministry of Religion cooperates with other ministries, the Ministry of Trade and Industry. The policy draft, if applied, can revive many real sectors in Indonesia, especially MSMEs and IKM.

Figure 4. Halal Certification Process

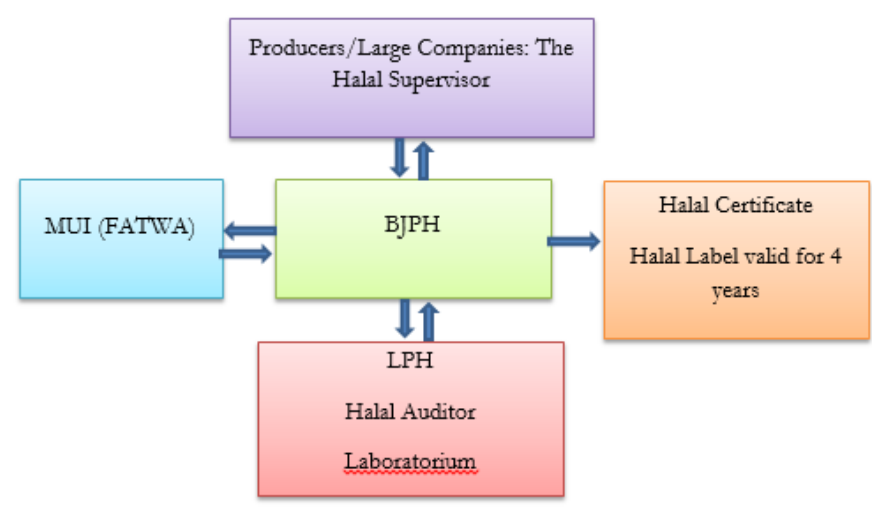

Source: www.kneks.go.id 
Figure 5. MSME Halal Certification Model

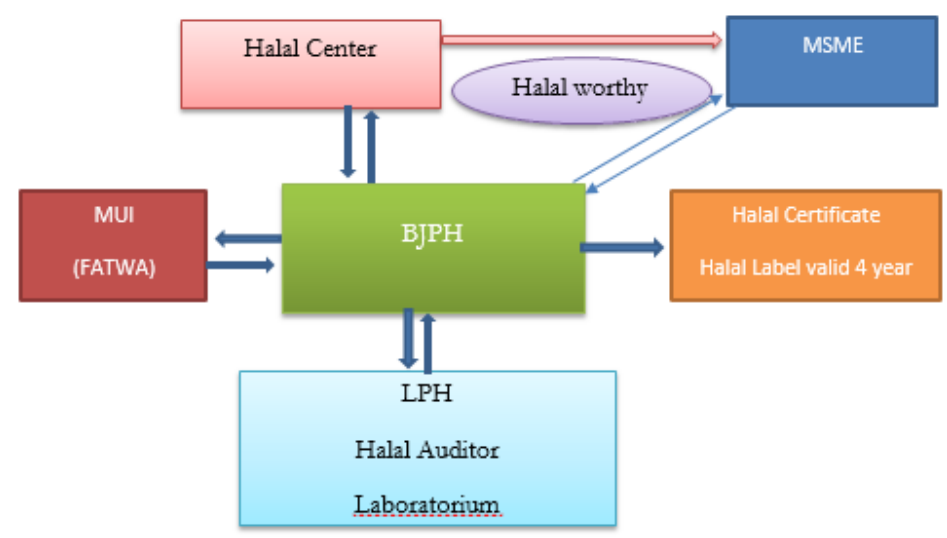

Source: www.kneks.go.id

The certification policy in Indonesia has not been implemented optimally. Currently, the policy is still being handled by the MUI and LPPOM MUI. The submission of the certification process is all done online. However, there is still a fee for each application for a halal certificate. This process and payment is often an obstacle in every halal certification. Because for MSMEs or IKMs with insufficient funds for halal, the process has a long flow and costs much money. Initially, halal certification was carried out voluntarily and not mandatory. LPPOM MUI carries it out, but currently, halal certification is mandatory and can be done by the government. The assigned LPH can be chosen freely by the halal food exporting company. The presence of this LPH assists BPJPH in examining halal products submitted by the company. In terms of cost, according to Yudi Hariyanto, it is not expensive. If an export company such as PT Mitratani Dua Tujuh is engaged in halal frozen food, and seven items will be exported, the cost is around Rp. 10,000,000. However, this cost will be covered by the presence of such great benefits from halal certification. Regarding costs, it can be seen in PMK No. 57 of 2021 regarding service rates for public service agencies of the Halal Product Assurance Organizing Agency.

Economica: Jurnal Ekonomi Islam - Volume 11, Nomor 1 (2020) 
Nikmatul Masruroh

Table 1. Number of LPPOM Halal Certification Products

\begin{tabular}{rrrr}
\hline Year & Number of Companies & Total Sh & Number of Products \\
\hline 2012 & 5.829 & 6.157 & 32.890 \\
2013 & 6.666 & 7.014 & 64,121 \\
2014 & 10,180 & 10.322 & 68,576 \\
2015 & 7,940 & 8,676 & 77,256 \\
2016 & 6.564 & 7.392 & 114.264 \\
2017 & 7.198 & 8157 & 127,286 \\
2018 & 11.249 & 17,398 & 204.222 \\
2019 & 13,951 & 15,495 & 274.796 \\
\hline
\end{tabular}

Source: LPPOM MUI (2019) at www.halalmui.org

Currently, the development of halal-certified food companies in Indonesia is increasing, as shown in the following table 1.

Based on Law No. 34 of 2014, it will be submitted to BPJPH under the Ministry of Religion, LPPOM MUI is only one of the existing LPHs in Indonesia. Before enacting the law, MUI thoroughly handled halal certification, but Law No. 33 of 2014 has brought changes in responsibilities. The MUI Halal logo is known worldwide and recognized by various halal certification bodies. Products that include halal labels are the primary choice for Muslims nationally and globally. Forty-eight foreign certification bodies have recognized halal certificates in 22 countries.

Meanwhile, on February 8, 2018, MUI has recognized foreign Certification Bodies (CB) from 45 countries. Since October 17, 2019, every food and beverage business must have a halal certificate. By having a halal certificate, products will have many competitive advantages. Today, a halal certification guarantees that a particular product has been thoroughly investigated and declared compliant with Islamic sharia law. Hence convincing Muslims to consume the product. According to Bukhari et al. (2019), consumer behavior has shifted from being concerned with healthy, 
Figure 6. Halal Food and Beverage Value Chain

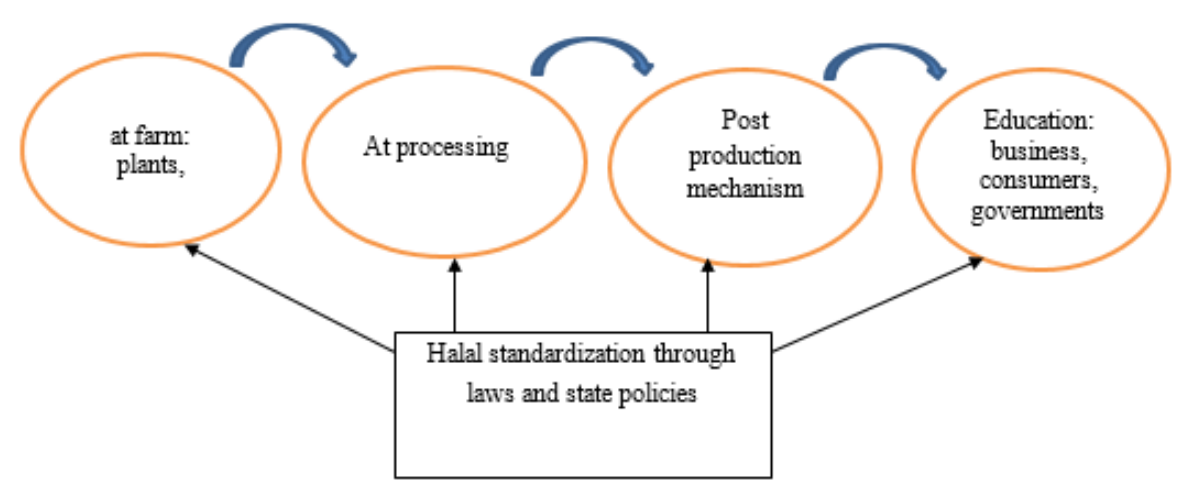

Source: Processed

halal, and safe food. Therefore, in Indonesia, halal certification adheres to traceability, i.e., the product must be traceable upstream. Therefore, if there is an unclean point, it can be immediately identified (the results of the FGD with the informants). The following shows the flow of the halal value chain in food and beverages:

The image as figure 6 . becomes a model developed for the halal food industry. In that industry, the change was standardization, which resulted in all things related to the industry having to be certified halal. So the halal industry is talking about labels and the company's compliance with halal standardization.

\section{Competitiveness of halal food exports in Indonesia}

Indonesia's position as a world market leader, especially in halal food, still looks weak. Table 2 shows Indonesia's place in the development of the world halal industry based on data published by GIEI in 2020: 
Nikmatul Masruroh

Table 2. Indonesia's Position in the Development of the Halal Industry

\begin{tabular}{cllllll}
\hline No & Halal Food & $\begin{array}{l}\text { Islamic } \\
\text { Finance }\end{array}$ & $\begin{array}{l}\text { Muslim } \\
\text { Friendly } \\
\text { Travel }\end{array}$ & $\begin{array}{l}\text { Modest } \\
\text { Fashion }\end{array}$ & $\begin{array}{l}\text { Pharma \& } \\
\text { Cosmetics }\end{array}$ & $\begin{array}{l}\text { Media \& } \\
\text { Recreation }\end{array}$ \\
\hline 1 & Malaysia & Malaysia & Malaysia & UAE & Malaysia & UAE \\
2 & Singapore & Saudi Arabia & UAE & Turkey & UAE & Malaysia \\
3 & UAE & UAE & Turkey & Indonesia & Singapore & Singapore \\
4 & Indonesia & Jordan & Thailand & Malaysia & Iran & United Kingdom \\
5 & Turkey & Bahrain & Tunis & Spain & Egypt & Indonesia \\
6 & Iran & Indonesia & Thailand & Italy & Indonesia & Brunei \\
7 & South Africa & Kuwait & Tunis & Bangladesh & France & Bahrain \\
8 & Pakistan & Pakistan & Azerbaijan & Canada & South Africa & Lebanese \\
9 & Brunei & Qatar & Jordan & France & Turkey & Kuwait \\
10 & Russia & Nigeria & Albania & Iran & Tunis & Netherlands \\
\hline
\end{tabular}

Source: The State Global Islamic Economic Report 2020/2021

From table 2, we can see that Indonesia's position has not been categorized as a significant player in the halal industry competition. Indonesia has the largest Muslim population, and Indonesia's halal consumption is the highest globally, namely 170 billion from 870 billion. This fact indicates that food export competitiveness Halal in Indonesia is still weak, proven by more imports than exports. However, through the report above, Indonesia can rank at number 4 based on the Global Islamic Economic Indicator Score Rank. This means that Indonesia's position in the halal industry is critical. Even though the opportunity to export halal food is vast, the potential for food is also enormous. Thomson Reuters provides data that there are new entrants in the halal industry as competitors from Indonesia. China invested AED1.35 billion in Dubai Food Park. Canada invested US\$10 million to improve halal processing capabilities. Kyrgyzstan prepared a roadmap for participating in halal food export. The Philippines enacted the 2016 Halal Export and Development Law and built a 100-hectare halal processing facility, whereas the country is not even a Muslim-based country.

In recent years, countries whose Muslim population is far below Indonesia have held the world's halal producer rankings. At the same time, the 
industry will compete if it can produce unique commodities among other sectors. Halal, in this case, is a symbol of uniqueness in the differentiation of food products that can be highlighted. In addition, "halal" is a product attribute that is taken into consideration for making decisions by consumers. last three years.

Table 3. is the ranking of the largest halal food-producing countries in the world for the. The data does not show Indonesia's ranking in the top ten halalproducing countries in 2018 and 2019. However, Indonesia showed progress in the halal food sector in 2020. Indonesia has a very high potential for halal products, and the potential occurred from various sectors, including the Indonesian people's cultural studies and consumption patterns. Nusantara culture is very thick with religious values, especially regarding halal. The culinary culture of the archipelago, both in food and drinks, is very rich in processed types, and the community has very much considered its halalness. Each region in Indonesia can be ascertained to have exceptional food and processed foods with a different taste. The taste of Indonesian food can always be said to suit the tongue of everyone from other parts of the country. When

Table 3. Ranking of Halal Food Exporting Countries

\begin{tabular}{clll}
\hline No & $\mathbf{2 0 1 8}$ & $\mathbf{2 0 1 9}$ & $\mathbf{2 0 2 0}$ \\
\hline 1 & UAE & UAE & Malaysia \\
2 & Malaysia & Malaysia & Singapore \\
3 & Brazil & Brazil & UAE \\
4 & Oman & Australia & Indonesia \\
5 & Jordan & Sudan & Turkey \\
6 & Australia & Pakistan & Iran \\
7 & Brunei & Oman & South Africa \\
8 & Pakistan & Brunei & Pakistan \\
9 & Sudan & Turkey & Brunei \\
10 & Qatar & Iran & Russia \\
\hline
\end{tabular}

Source: GIEl Reports for 2018/2019, 2019/2020 and 2020/2021

Economica: Jurnal Ekonomi Islam - Volume 11, Nomor 1 (2020) https://journal.walisongo.ac.id/index.php/economica 
Nikmatul Masruroh

there is an exchange of students/students between countries, the stories of Indonesian students/students abroad always try to adapt to the food of the local country. On the other hand, overseas students who study/study in Indonesia state the suitability and enjoyment of the archipelago's culinary arts (Nurhasah, Munandar, and Syamsun 2018).

Based on the data above and interviews and FGDs, Indonesia continues to develop the halal industry to increase its competitiveness in the halal industry. Indonesia is currently in the fourth position in the halal food industry, meaning that it has increased compared to 2018 and 2019, which have not yet entered the top 10 in the competition for the halal food industry. According to Sukoso, it was conveyed that the principle of traceability applied to the halal industry in Indonesia has increased the position of trust of importing countries in food products in Indonesia. If other countries use, halal is only used to sell their products. So in Indonesia, the halal label must be accountable from upstream to downstream. So, currently, the position of halal food companies originating from Indonesia is competing in an oligopoly market, for example, PT. Indofood, PT Mitratani Dua Tujuh and so on.

In addition, as the formulation already disclosed, exports have a substantial impact on GDP. Therefore, indicators of economic growth can be seen from the development of GDP owned. If exports increase, GDP will also increase, so the economy continues to grow. Indonesian economic indicators: Gross Domestic Product (GDP), Money Supply, Inflation, Foreign Currency Value Against Rupiah, and Import Exports. One of the export indicators is nonoil and gas exports (in the form of commodities), one of which is food exports, both halal and non-halal (www.kemendag.go.id).

From this data, food still occupies the first position in Indonesia's exports, meaning that the highest contributor to export income is from the food sector in terms of economic growth. However, the Ministry of Industry has not separated the halal food industry and not. At least this informs that the halal food industry has great opportunities in the world of exports. According to a 
Bank Indonesia Report, in the fourth quarter of 2017, export performance reached $8.5 \%$ contributing to Indonesia's economic growth. The data is reinforced by databoks.katadata.co.id. The Central Statistics Agency data shows that the food and beverage industry grew by $2.03 \%$ annually in January-June 2020 due to COVID-19.

According to the results of FGD, has been no significant separation between the export of food with a halal and non-halal label. So, in terms of the contribution of halal food exports to Indonesia's economic growth, it has not been seen with certainty because the food and beverage industry is one industrial unit. Nevertheless, in the current competitive position, the Indonesian halal food industry has increased to penetrate the market to various countries globally, such as Turkey, UAE, Dubai, etc.

Figure 7. Export Value as of June 2018 by www.kemendag.go.id

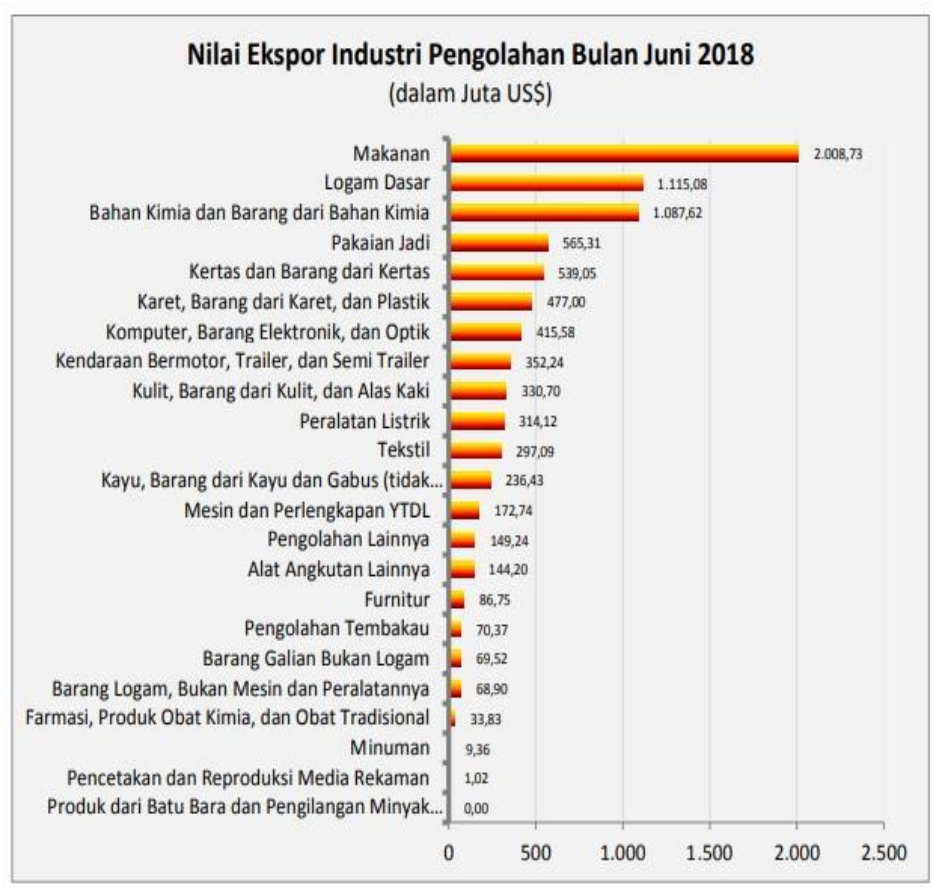

Economica: Jurnal Ekonomi Islam - Volume 11, Nomor 1 (2020) https://journal.walisongo.ac.id/index.php/economica 


\section{Conclusion}

Institutional problems are still the cause of the undeveloped halal food industry in Indonesia. The transition of the halal certification system from MUI to BPJPH has changed the procedures for implementing halal certification in Indonesia. The food industry, the primary industry that must have halal certification, has not been detected in numbers for the level of exports carried out. Although according to the GIEI report for 2020/2021, the ranking of the Indonesian halal food industry had increased from before, which was not in the top 10, it could enter the fourth rank. The principle of traceability can be an advantage of halal certification applied in Indonesia, compared to other countries. So, this research produces the first halal value chain policy stated in the Halal Product Guarantee Law No. 33 of 2014, which requires all food entrepreneurs to carry out halal certification. The halal value chain in Indonesia applies the principle of traceability which makes Indonesian halal food products competitive. The second application of the principle of traceability is different from other countries, making halal food products produced by Indonesia acceptable to importing countries, especially OIC countries.

\section{References}

Abdul Rahman, N. A., Mohammad, M. F., Abdul Rahim, S., \& Mohd Noh, H. (2018). Implementing Air Cargo Halal Warehouse: Insight From Malaysia. Journal of Islamic Marketing, 9(3), 462-483. https://doi.org/10.1108/JIMA-09-2016-0071

Abu-alhaija, A. S. (2018). Religion in Consumer Behaviour Research: The Significance of Religious Commitment and Religious Affiliation. International Journal of Economics, Commerce and Management, VI(1), 245-258.

Al Qardhawi, Yusuf. (1993). Halal Wal Haram Fi Islam. Damaskus: Dar al Fikr Atalan-Helicke, N. (2015). The Halal Paradox: Negotiating Identity, Religious Values, and Genetically Engineered Food in Turkey. Agriculture and 
Human Values, 32(4), 663-674. https://doi.org/10.1007/s10460-0159585-z

Az-Zuhaili, Wahbah. (1985). al Fiqhul Islami Waadillatuhu. Damaskus: Dar al Fikr

Bukhari, S., Woodside, F., Hassan, R., Shaikh, A., Hussain, S., \& Mazhar, W. (2019). Is Religiosity an Important Consideration in Muslim Consumer Behavior: Exploratory Study In the Context of western imported food in Pakistan. Journal of Islamic Marketing, 10(4). https://doi.org/10.1108/JIMA-01-2018-0006

Romer, David. (2012). Advanced Macroeconomics. McGrawHill: California

Elias, S., \& Noone, C. (2016). The Growth and Development of the Indonesian Economy, Buletin, December, 33-44.

Endang S Soesilowati. (2010). Business Opportunities for Halal Products in the Global Market: Muslim Consumer Behaviour and Halal Food Consumption. Journal of Indonesian Social Sciences and Humanities, 3(May 2007), 151-160.

Hameeda, S., Gillani, B., Ijaz, F., Officer, A., Mahmood, M., \& Khan, S. (2016). Role of Islamic Financial Institutions in Promotion of Pakistan Halal Food Industry, Islamic Banking and Financial Review 3(1), 29-49.

Ismoyowati, D. (2015). Halal Food Marketing: A Case Study on Consumer Behavior of Chicken-based Processed Food Consumption in Central Part of Java, Indonesia. Agriculture and Agricultural Science Procedia, 3, 169172. https://doi.org/10.1016/j.aaspro.2015.01.033

Jaya, I., \& Luhur, U. B. (2018). Implementasi Supply Chain Management (SCM) Berbasis Web Pada Departemen Weaving I Guna Mengatasi Keterlambatan, https://researchgate.net/publication/323906035 (March).

Koo, R. C. (2016). The other half of macroeconomics and the three stages of economic development. Real-World Economics Review, (75), 2-49.

Kusuma, D. B. W., Muqorrobin, M., Krouchj, C., \& Jamaluddin, N. (2013). The Rational Behavior Concept in Islam and Policy Framework Perspectives. Global Review of Islamic Economics and Business, 1(2), 099-118. 
Nikmatul Masruroh

Mei, J., Mahmood, S., Joe, C., Regenstein, M., Soon, J. M., \& Regenstein, J. Mac. (2017). Halal integrity in the food supply chain. https://doi.org/10.1108/BFJ-04-2016-0150

Mohammed, A., Wang, Q., \& Li, X. (2017). A cost-effective decision-making algorithm for an RFID-enabled HMSC network design A multi-objective approach. Industrial Management and Data Systems, 117(9). https://doi.org/10.1108/IMDS-02-2016-0074

Mostafa, M. M. (2020). A knowledge domain visualization review of thirty years of halal food research: Themes, trends and knowledge structure. Trends in Food Science and Technology, 99. https://doi.org/10.1016/j.tifs.2020.03.022

Nurhasah, S., Munandar, J. M., \& Syamsun, M. (2018). Faktor-Faktor yang Mempengaruhi Minat Beli Produk Makanan Olahan Halal pada Konsumen. Jurnal Manajemen Dan Organisasi, 8(3), 250. https://doi.org/10.29244/jmo.v8i3.22473

Blanchard, Olivier (2017). Macroeconomics. Boston: Pearson

Ratanamaneichat, C., \& Rakkarn, S. (2013). Quality Assurance Development of Halal Food Products for Export to Indonesia. Procedia - Social and Behavioral Sciences, 88(July), 134-141. https://doi.org/10.1016/j.sbspro.2013.08.488

Ruiz-Bejarano, B. (2017). Halal Global Trade, Islamophobia StudiesJournal, Vol. 4(1), 129-145.

Saabar, S. S., \& Ibrahim, S. B. (2014). The Knowledge of Halal and Advertising Influence on Young Muslims Awareness, 36-39. https://doi.org/10.7763/IPEDR.

Waharini, F. M., \& Purwantini, A. H. (2018). Model Pengembangan Industri Halal Food di Indonesia Model Pengembangan Industri Halal Food di Indonesia, Muqtasid (July). https://doi.org/10.18326/muqtasid.v9i1.113

Yusoff, F. A. M., Yusof, R. N. R., \& Hussin, S. R. (2015). Halal Food Supply Chain Knowledge and Purchase Intention. International Journal of Economics and Management, 9(Special Issue), 155-172. https://doi.org/10.1002/pssr.201105388 